\begin{tabular}{ll}
\hline POLITEIA & POLITEIA: Jurnal Ilmu Politik \\
& Politeia, 11 (2) (2019): 1-18 \\
ISSN 0216-9290 (Print), ISSN 2549-175X (Online) \\
Available online https:/ / talenta.usu.ac.id/politeia
\end{tabular}

\title{
Sistem Pemilihan Kepala Desa dan Pengangkatan Lurah serta Pengaruhnya terhadap Pelayanan Publik : Studi Kasus Perbandingan di kota Jambi dan Muaro Jambi
}

\author{
Haris Mubarak* \& Indra Fauzan \\ Universitas Islam Negeri (UIN) Sulthan Thaha Saifuddin Jambi \\ Institut Kajian Etnik (KITA), UKM
}

\begin{abstract}
Abstrak
Pemilihan kepala desa secara langsung di satu sisi bersesuaian dengan sistem demokrasi, tetapi di sisi lainnya, sistem seperti ini menggunakan banyak dana serta seringkali terjadi konflik antara kedua pihak. Manakala lurah yang diangkat oleh pejabat di atasnya tidak banyak menimbulkan isu-isu konflik. Oleh itu, tulisan ini bertujuan untuk menguji tingkat pelayanan umum di desa dan kelurahan berdasarkan sistem pemilihan kepala desa secara langsung oleh masyarakat dan lurah yang diangkat oleh pejabat di atasnya. Kajian ini menggunakan metode kuisioner yang dijalankan di 60 desa dan kelurahan di kabupaten Muaro Jambi dan Kota Jambi. Manakala untuk menganalisa data, kajian ini menggunakan tekhnik analisis data uji Tau-b dan Mann-Whitney. Hasil kajian menunjukkan bahwa tidak terdapat pengaruh pemilihan kepala desa dan lurah terhadap pelayanan publik, tetapi dari aspek pelayanan publik, perbezaan hanya terletak pada nilai pelayanan di desa sebesar 52,49, manakala di keluarahan sebesar 47,39. Oleh kerana itu, pemilihan maupun pengangkatan kepala desa atau lurah tidak membawa dampat langsung terhadap pelayawan publik. Ada faktor-faktor lain yang mempengaruhi pelayanan tersebut.
\end{abstract}

Kata Kunci: Kepala Desa, Lurah, Pemilihan Langsung, Pengangkatan

\section{Abstrak}

Direct election for a chief village in one side is suitable with democratic practice, but on the other side, this sistem needs much cost and often occurs conflict between two parties. Otherwise, the chief urban village that is appointed by the higher official is not many relating to conflict issues. Therefore, this study aims to examine the practice of public services in the village and urban village based on direct chief village election and appointed chief urban village. This research uses questionnaires distributed in 60 villages and urban village in Muaro Jambi Regency and Jambi city. While to analyze this data, this research uses Tau-b and Mann-Whitney technique analysis. The result of this study shows that there is no correlation between direct chief village local election and appointed chief urban village and public services, but from public services in both areas, there is a difference between them, The difference is in the value of public services, there are 52,49 for village and 47,30 for the urban village. Therefore, there is no direct impact on direct chief village election and appointed chief urban village. There are other factors that influence public services in both areas.

Keywords: Chif Village, Chief Urban Village, Direct Election and Appoitment

How to Cite: M. Haris \& F. Indra (2019). Sistem Pemilihan Kepala Desa dan Pengangkatan Lurah serta Pengaruhnya terhadap Pelayanan Publik : KES Perbandingan di Kota Jambi dan Muaro Jambi, Politeia: Jurnal Ilmu Politik, 11 (2): 1-18

\footnotetext{
${ }^{*}$ Corresponding author:

E-mail: Haris_mubarak@uinjambi.ac.id
} 


\section{PENDAHULUAN}

Pemilihan kepala desa di Indonesia dilaksanakan secara langsung, di mana masyarakat desa dapat menentukan sendiri siapa kepala desa mereka sesuai dengan hati nuraninya. Sistem ini merupakan sebuah gambaran dari praktik demokrasi di Indonesia pada peringkat paling bawah yang harus dilaksanakan secara adil, jujur, bebas dan rahasia (Peraturan Menteri Dalam Negeri No. 112 Tahun 2014 Pasal 1(5)). Namun sistem pemilihan ini tidaklah diikuti dalam memilih kepala kelurahan (lurah), di mana lurah diangkat oleh pejabat diatasnya. Kedudukan kepala desa dan lurah pada dasarnya tidak jauh berbeda dan keduanya sama-sama terletak di bawah pemerintahan kecamatan, yang membedakannya adalah kedudukan wilayah, jumlah penduduk dan status kepala desa dan kepala kelurahan, di mana kepala desa bukanlah Aparatur Sipil Negara (ASN) atau pegawai kerajaan, sedangkan lurah adalah seorang birokrat yang terikat dengan aturan pegawai kerajaan.

Pemilihan kepala desa pada pemilih di desa seperti di desa yang satu sisi merupakan cerminan dari memiliki jumlah mata pilih mencapai

demokrasi untuk melibatkan masyarakat dalam menentukan pemimpin mereka sendiri sehingga diharapkan pemimpin terpilih dapat membangun desa dan mensejahterakan masyarakat desa. Dalam penelitian Yuningsih and Subekti (2016) di tiga desa di Kecamatan Selawu misalnya menunjukkan bahwa pelaksanaan demokrasi telah berjalan dengan baik, di mana partisipasi efektif dalam masyarakat dan kontrol terhadap agenda politik berjalan, meskipun kriteria lain seperti kesetaraan pilihan, pemahaman mereka dalam menentukan pilihan terbaik dan tidak ada pengeculian terhadap pemilih masih belum terpenuhi. Tetapi pada sisi lain, praktik pemilihan kepala desa seringkali memunculkan persoalan, sebagai contoh dana untuk pemilihan kepala desa serentak saja di Kabupaten Demak sama dengan dana yang diperlukan untuk pemilihan kepala daerah setingkat bupati dengan biaya 16 Miliar Rupiah (Tempo 2016). Sedangkan di kabupaten Tegal, dana untuk pemilihan kepala desa diberikan pemerintah bergantung dengan jumlah 
25000 akan diberikan dana 25 juta pemilihan kepala desa tersebut. Rupiah sedangkan di atas 2500-5000 Selanjutnya Fitriyah (2015) dan orang akan didanai 30 juta Rupiah Aspinall dan Rohman (2017) (Tribunjateng 2018). menemukan bahwa membeli suara

Dana di atas belum termasuk atau politik uang menjadi strategi utama untuk memenangkan pemilihan uang yang dikeluarkan oleh kandidat atau calon kepala desa, dari mulai pendaftaran, kampanye maupun pembiayaan mesin politiknya. Sebagai kepala desa, di mana uang diberikan kepada pemilih melalui para broker politik mereka

contoh di Desa Muara Baru di Kajian lain juga menunjukkan Kabupaten Ogan Komering Ilir, bahwa pemilihan kepala desa rentan Sumatera Selatan, di mana calon kepala terhadap konflik kekerasan antara desa harus membayar uang sebesar 39 penyokong kandidat (Kingsley 2012), juta Rupiah untuk boleh ikut dan beberapa kasus penyelesaian mendaftar sebagai calon (Tribunnews konflik pemilihan kepala desa banyak 2015) dan pemungutan dana sebesar 65 yang belum terselesaikan, karena juta Rupiah yang diminta oleh panitia kurangnya aturan hukum yang pemilihan kepala desa di Desa Karpote mengatur persoalan tersebut dan di Jawa Timur yang kemudian kurangnya kompetensi tim investigasi membuat laporan terhadap kasus yang mengatur masalah administrasi tersebut ke polisi (Tempo 2015).

(Kartika 2016). Di samping itu, korupsi

Di samping itu dalam kajian Aspinall and Rohman (2017) bahwa pemilihan kepala desa menunjukkan kandidat kepala desa hanya diisi orang-orang yang memiliki kemampuan finansial, mereka ini akan menginvestasikan dana mereka dan sumber-sumber politik di dalam juga sangat rentan terjadi di desa, apatah lagi dana yang diberikan oleh pemerintah mencecah 1 miliar Rupiah pertahun, sehingga tingkat rasuah di desa naik peringkat dari 17 kasus rasuah kepala desa pada tahun 2015, kemudian meningkat menjadi 41 kes pada tahun 2016 dan 96 kes pada 2017 (Indonesian Corruption Watch 2018). 
Jika dibandingkan dengan institusi-institusi penyokong kinerja lurah, maka persoalan konflik tidak pemerintah (Savas 1987).

begitu banyak terjadi, apalagi dana yang diberikan untuk pembangunan kelurahan tidak sebesar dana desa, sehingga ada kelurahan yang ingin menjadi desa yang disebabkan oleh motif ekonomi dan politik (Harsanto et al. 2017). Persoalan yang perlu menjadi perhatian adalah bagaimanakah efek pemilihan kepala desa dan pengangkatan lurah ini terhadap pelayanan publik. Ini karena, hasil yang diharapkan dari proses pemilihan tersebut bertujuan meningkatkan pelayanan kepada masyarakat.

Sementara itu, pelayanan publik merupakan sesuatu yang sangat penting dalam penyelenggaraan pemerintahan, segala bentuk pelayanan barang dan jasa dari pemerintah kepada masyarakat menjadi tugas utama dalam penyelenggaraan pemerintahan (Fadhillah 2012, Dwiyanto 2015), sedangkan pelayanan pemerintah merupakan suatu kemestian yang Pelayanan publik menjadi dilakukan oleh agen-agen pemerintah masalah ketika negara atau pemerintah iaitu para pegawainya melalui sektor- tidak mampu memberikan pelayanan sektor publik yang kita kenali dengan publik yang baik kepada masyarakat, 
untuk itu mengikut Sinambela (2006) dilaksanakan secara demokrasi dan mengatakan bahwa untuk mencapai pengangkatan lurah oleh pejabat di pelayanan prima maka harus tercermin atasnya terhadap pelayanan publik di daripada beberapa aspek seperti : desa dan kelurahan. Dalam konteks transparansi, akuntabilitas, demokrasi, seharusnya pemilihan kondisional, partisipatif dan kesamaan kepala desa dapat memberikan hak. Untuk itu penyediaan pelayanan pengaruh terhadap pelayanan publik publik menjadi sangat penting ketika daripada kelurahan.

selarinya pelayanan dan kepuasaan.

Muara daripada semua itu adalah

REKA BENTUK KAJIAN

bagaimana kepuasan masyarakat mendapat layanan daripada pemerintah sesuai dengan peraturan perundang-undangan yang berlaku. Apalagi dalam konteks zaman sekarang inovasi pelayanan sudah harus berbasis teknologi, dengan segala macam ekses dan kemudahan, inovasi tekhnologi ini harusnya menjadi penggiat untuk para pejabat terkai bawa pelayanan publik agar lebih bergiat untuk mempertingkatkan kualitas pelayanan kepada masyarakat tidak hanya sumber daya manusia saja tetapi juga menyangkut kenyamanan fasilitas, sistem dan tentunya pelayanan publik.

Oleh karena itu, penelitian ini bertujuan untuk membandingkan pemilihan kepala desa yang

Dalam penelitian ini, akan dihuraikan mengenai teori-teori yang berkaitan dengan variabel penelitian ini, sistem pengangkatan Kepala Desa dan Lurah sebagai variabel independent $(\mathrm{X})$, pelayanan publik aparatur desa dan kelurahan sebagai variabel dependent $\left(\mathrm{Y}_{2}\right)$. Penelitian ini menggunakan metod survey dengan teknik causalcomparative. Penelitian survey menurut Kerlinger (2004:660) adalah penelitian yang mengkaji populasi, namun data yang digunakan merupakan data sampel yang diambil dari populasi, sehingga ditemukan insidensi, distribusi dan interelasi relatif dari variabel-variabel sosiologis maupun psikologis. Pilihan terhadap pendekatan kausal dikeranakan dalam penelitian ini menguji hubungan 
kausal yaitu pengaruh praktik kelurahan akan menjadi responden dalam pemilihan Kepala Desa dan penelitian ini.

pengangkatan Lurah terhadap pelayanan publik aparatur Desa dan

\section{METODE PENELITIAN}

Lurah. Sedangkan pendekatan Pelayanan publik adalah tugas komparatif untuk melihat perbedaan memberikan pelayanan kepada kinerja dan pelayanan publik antara masyarakat tanpa membeda-bedakan aparatur Desa dan Kelurahan.

\section{KRITERIAN PEMILIHAN SAMPEL KAJIAN}

Penelitian ini dilaksanakan di Kota Jambi dan Kabupaten Muaro Jambi yang dilaksanakan di 60 desa dan kelurahan. Kedua wilayah ini dipilih karena Kota Jambi dan Muaro Jambi sangat dekat sehingga mobilitas penduduk kedua daerah ini saling bertukar antara satu sama lainnya dan dapat merasakan apa yang terjadi di kelurahan dan di desa. pelayanannya dan pelayanan ini diberikan tanpa ada pengutipan biaya atau dengan biaya sedemikian rupa (Dwiyanto 2006). Pasolong (2007:128) menyatakan bahwa pelayanan adalah aktiviti seseorang, sekelompok atau organisasi baik langsung maupun tidak langsung untuk memenuhi keperluan. Jika dilihat dalam perspektif pemerintah, pelayanan publik diartikan sebagai “segala kegiatan pelayanan yang dilaksanakan oleh penyelenggara pelayanan publik sebagai upaya pemenuhan keperluan penerima pelayanan maupun pelaksanaan

Teknik sampling dilakukan peraturan perundang-undangan." berdasarkan kelompok (cluster sampling) (Sedangkan hakikat pelayanan publik yang dilakukan dengan dua tahap yaitu menurut keputusan menteri ini adalah sampel daerah ditentukan terlebih dahulu masyarakat akan memperoleh pelayanan dari 151 desa dan 67 kelurahan di kedua prima dari pemberi pelayanan sebagai wilayah. Tahap selanjutnya adalah bentuk kewajiban aparatur pemerintah menentukan individu-individu yang sebagai pelayan masyarakat (Keputusan menjadi responden dengan tekhnik Menteri Pendayagunaan Aparatur Negara accidental sampling yaitu masyarakat yang Nomor 63/KEP/M.PAN/\&/2003). sedang berurusan di kantor desa atau 
Berdasarkan keperluan masayarakat dimensi Tangibels dengan indikator akan pelayanan publik yang berkualiti tampilan dan fasilitas sarana dan yang disediakan oleh pemerintah, maka prasarana serta tampilan peralatan dan sebagai pelayan publik pemerintah dalam perlengkapan yang menunjang hal ini aparatur desa dan kelurahan harus pelayanan. Dimensi reliability dengan senantiasa mengacu pada kepuasan indikator kemampuan menyelesaikan masyarakat sebagai tujuan utama dalam tugas pelayanan tepat waktu serta pelayanan publik. Dalam menilai kemampuan memberikan pelayanan pelayanan publik, adapun dimensi- secara benar sesuai jenis pelayanan. dimensi pelayanan publik menurut Dimensi responsiveness dengan indikator Zeithanml dkk dalam Pasolong (2010:135) memberikan pelayanan cepat tanggap adalah tangibels, reliability, responsiveness, serta kesadaran atau keinginan untuk Assurance dan Empathy.

membantu dan tidak menyulitkan

Untuk mengukur kualitas pelayanan konsumen. Dimensi Assurance dengan indikator memiliki pengetahuan dalam publik, penelitian ini menggunakan kuisioner dengan skala likert dengan 4 pilihan jawaban dalam pernyataan. Pernyataan tersebut terdiri dari pernyataan positif dan pernyataan negatif. Untuk kalimat positif, jawapan selalu (SL) diberi skor 4, sering (S) diberi skor 3, memberi pelayanan serta adanya kemampuan pemberi layanan untuk menimbulkan keyakinan pada masyarakat. Dimensi empathy dengan indikator kepedulian dan perhatian terhadap pengguna layanan. kadang-kadang (K) diberi skor 2, dan tidak pernah (TP) diberi skor 1, sedangkan untuk kalimat negatif, jawapan selalu (SL) diberi skor 1, sering (S) diberi skor 2, kadang-kadang (K) diberi skor 3, dan tidak pernah (TP) diberi skor 4 .

Adapun dimensi yang diukur menggunakan skala likert ini adalah

\section{VALIDITAS DAN REABILITAS DATA}

Suatu instrumen dikatakan valid apabila instrumen tersebut dapat mengukur dengan tepat apa yang diukur. Untuk melakukan pengujian validitas, peneliti menggunakan formula Pearson Product Moment yaitu dengan mengkorelasikan skor tiap item dengan skor total responden. Hasil 
korelasi tiap butir item dikonsultasikan mengetahui dan menganalisis dengan $\mathrm{r}$ tabel pada taraf kesalahan 5\% perolehan skor jawapan responden per dengan $\mathrm{n}=30, \mathrm{dk}=\mathrm{n}-2(30-2=28)$, indikator dari setiap dimensi maka diperoleh $r$ tabel sebesasar 0,37. pelayanan publik, dapat didasarkan Dari hasil pengujian, maka butir item pada kriteria penilaian dengan skala pernyataan dianggap valid. interval jawapan responden sebagai berikut:

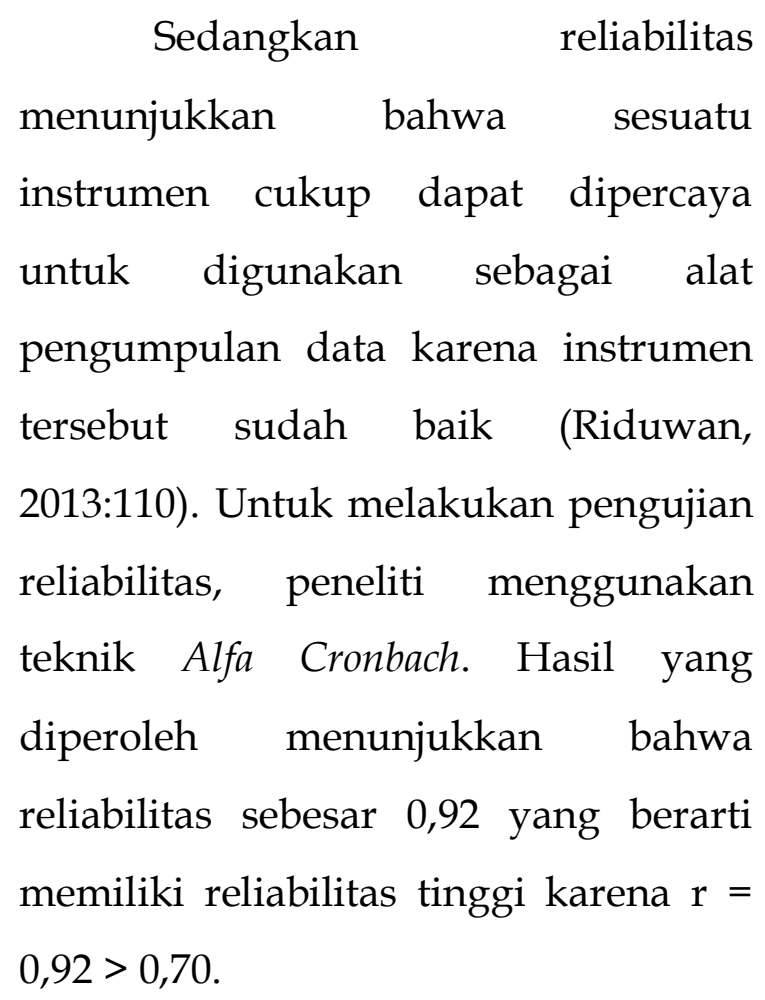

\section{TEKNIK ANALISIS DATA}

Tekhnik yang digunakan dalam menganalisis data penelitian terdiri dari analisis deskriptif dan analisis inferensial non parametris. Analisis deskriptif dilakukan untuk mencari koefisien mean, median, modus, simpangan baku, varians, pembuatan distribusi frekuensi dan histogram dari skor setiap variabel penelitian. Untuk
(1) 180 responden $\times 1$ item pernyataan $\times 1$ (skor) $=180$ (tidak baik)

(2) 180 responden $\times 1$ item pernyataan $\times 2$ (skor) $=360$ (cukup baik)

(3) 180 responden $\times 1$ item pernyataan $\times 3$ (skor) $=540$ (baik)

(4) 180 responden $\times 1$ item pernyataan $\times 4$ (skor) $=720$ (sangat baik)

Sedangkan analisis inferensial digunakan untuk mengetahui pengaruh sistem pemilihan Kepala Desa dan pengangkatan Lurah terhadap pelayanan publik aparatur desa dan lurah, serta mengetahui perbedaan pelayanan publik antara aparatur desa dan lurah.

Dalam penelitian ini, data penelitian dianalisis dengan statistik non parametris menggunakan formula uji Tau-b, dimana koefisien kontingensi 
digunakan untuk mengukur pengaruh sistem pemilihan Kepala desa dan Pengangkatan Lurah terhadap terhadap pelayanan publik aparatur Desa dan Lurah. Sedangkan uji MannWhitney Mann-Whitney digunakan untuk mengukur perbedaan pelayanan publik antara aparatur desa dengan aparatur kelurahan ditinjau berdasarkan sistem pemilihan Kepala Desa dan penentuan Lurah.

\section{HASIL KAJIAN DAN}

\section{PERBINCANGAN}

Pelayanan Publik di Desa dan Kelurahan untuk memberikan gambaran dari hasil skor perindikator menurut dimensi pelayanan publik aparatur desa dan kelurahan di Muaro Jambi dan Kota Jambi dari dimensi tangibels menunjukkan bahwa pelayanan publik di desa dalam kategori cukup baik. Hal ini juga tidak jauh berbeda dengan pelayanan publik pada peringkat kelurahan dan kelurahan dalam kategori cukup baik, meskipun nilai yang diperoleh berbeda (Tabel 1) dan ini dapat digambarkan dengan skala interval seperti gambar berikut:
Gambar 1 Skala Interval Pelayanan Publik Desa dan Kelurahan

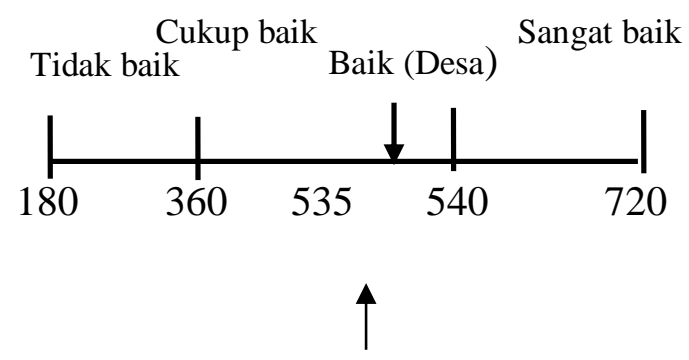

Baik (kelurahan)

Tabel 1 dimensi tangibels pelayanan publik aparatur desa

\begin{tabular}{|c|c|c|c|}
\hline Indikator & & Desa & \\
\hline & Skor & Kriteria (\%) & Ket. \\
\hline $\begin{array}{l}\text { Kenyamana } \\
\text { n fasilitas }\end{array}$ & 553 & $\frac{553}{720} \times 100=77$ & Baik \\
\hline prasarana & 537 & $\frac{537}{720} \times 100=75$ & $\begin{array}{c}\text { Cukup } \\
\text { Baik }\end{array}$ \\
\hline $\begin{array}{l}\text { Peralatan } \\
\text { dan } \\
\text { perlengkap }\end{array}$ & 514 & $\frac{514}{720} \times 100=71$ & $\begin{array}{c}\text { Cukup } \\
\text { Baik }\end{array}$ \\
\hline $\begin{array}{l}\text { an yang } \\
\text { mendukun }\end{array}$ & 534 & $\frac{534}{720} \times 100=74$ & $\begin{array}{c}\text { Cukup } \\
\text { Baik }\end{array}$ \\
\hline $\begin{array}{l}\text { g } \\
\text { pelayanan }\end{array}$ & & & \\
\hline Rata - rata & 535 & & $\begin{array}{c}\text { Cukup } \\
\text { Baik }\end{array}$ \\
\hline
\end{tabular}

Tabel 2 dimensi tangibels pelayanan publik aparatur kelurahan

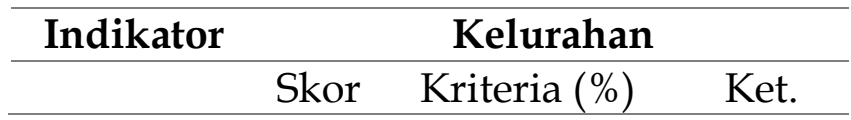




$$
\begin{array}{lclc}
\hline \begin{array}{c}
\text { Kenyamana } \\
\text { n fasilitas } \\
\text { sarana dan } \\
\text { prasarana }
\end{array} & 545 & \frac{545}{720} \times 100=76 & \text { Baik } \\
\cline { 2 - 4 } & 508 & \frac{508}{720} \times 100=71 & \begin{array}{c}
\text { CukupTabel } 4 \text { Hasil analisis skor dimensi } \\
\text { baik reliability pelayanan publik aparatur } \\
\text { Kelurahan }
\end{array} \\
\hline \begin{array}{l}
\text { Peralatan } \\
\text { dan }
\end{array} & 459 & \frac{459}{720} \times 100=64 & \begin{array}{c}
\text { Cukup } \\
\text { baik }
\end{array}
\end{array}
$$$$
\begin{array}{llllccc}
\text { perlengkap } & & \multicolumn{3}{c}{\text { Indikator }} & \multicolumn{3}{c}{\text { Kelurahan }} \\
\cline { 2 - 5 } \begin{array}{l}
\text { an yang } \\
\text { pendukung }
\end{array} & 496 & \frac{496}{720} \times 100=69 & \begin{array}{c}
\text { Cukup } \\
\text { baik }
\end{array} & \text { Sko } & \text { Kriteria }(\%) & \text { Ket. } \\
\text { pen } & & \text { r } & &
\end{array}
$$$$
\text { pelayanan }
$$$$
\text { Rata - rata } 502
$$$$
\begin{array}{ccc}
\text { Kemampuan } & 446 & \frac{446}{720} \times 100=62 \\
\text { Cukmpnyelesaikan } & \text { Cukup } \\
\text { Baik }
\end{array}
$$$$
\text { baik tugas }
$$$$
\text { pelayanan tepat }
$$

Dari aspek Reliability kemampuan waktu menyelesaikan tugas dan kemampuan $\begin{aligned} & \text { Kemampuan } \\ & \text { memberikan }\end{aligned} \quad 523 \frac{523}{720} x 100=73 \begin{aligned} & \text { Cukup } \\ & \text { Baik }\end{aligned}$ memberikan pelayanan di desapelayanan menunjukkan kateogri baik. Hal ini secara $\begin{gathered}\text { benar } \\ \text { jenis }\end{gathered} \frac{514}{720} x 100=71$ Cukup berbeza dengan kelurahan yang diisipelayanan

\begin{tabular}{lllll} 
oleh Aparatur Sipil Negara (ASN) & Rata - rata 494 & Cukup \\
& & Baik \\
\hline
\end{tabular}
yang hanya menunjukkan kategori cukup baik.

Tabel 3 Hasil analisis skor dimensi reliability pelayanan publik aparatur desa

Kemudian dari aspek responsiveness pelayanan publik aparatur desa dan kelurahan dapat dilihat pada tabel 3, di mana pelayanan publik aparatur desa pada

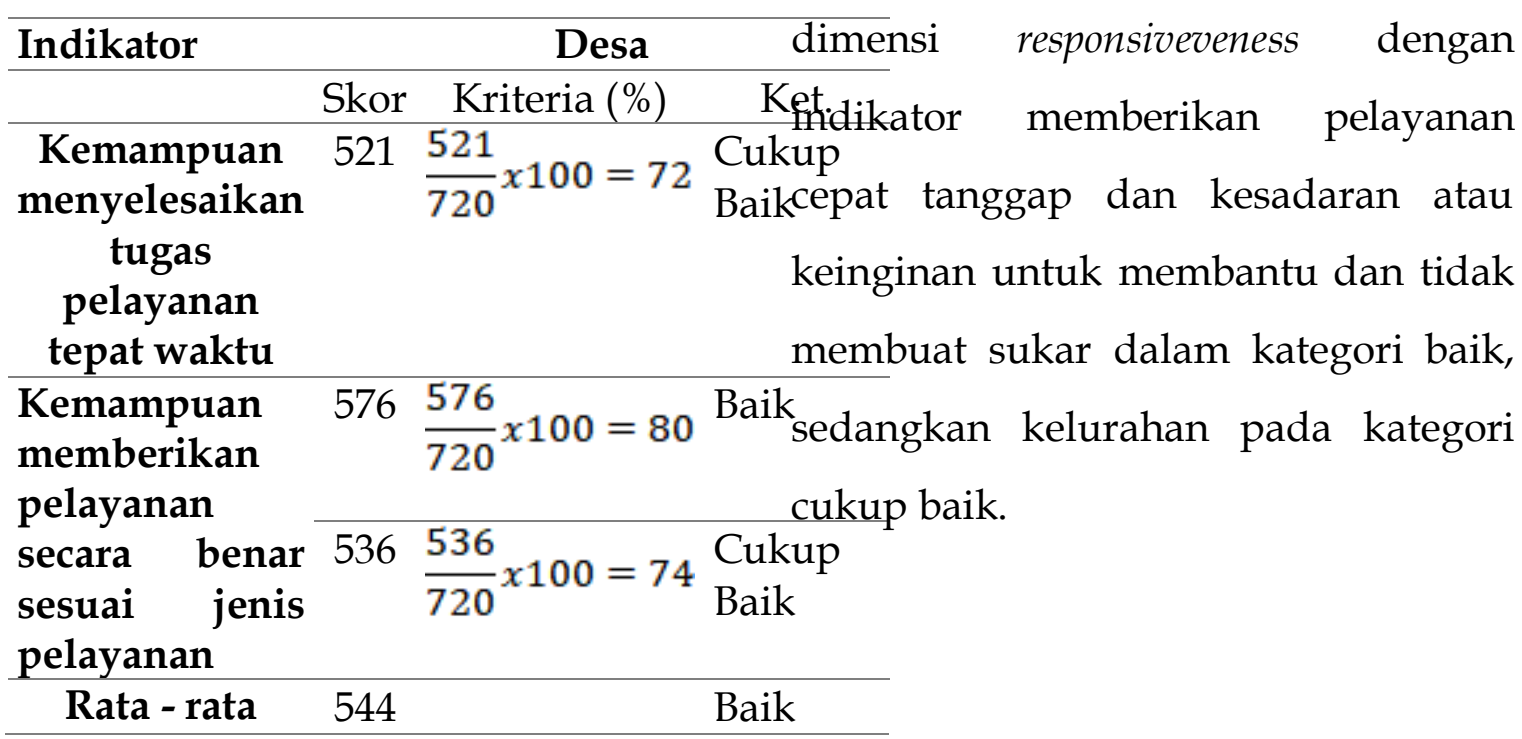


Tabel 5 Hasil analisis skor dimensi responsiveness pelayanan publik aparatur desa
Selanjutnya dilihat dari aspek assurance, maka nilai pelayanan publik aparatur desa dalam kategori baik sedangkan untuk kelurahan dalam

\begin{tabular}{c}
\hline Indikator \\
\hline $\begin{array}{c}\text { Memberikan } \\
\text { pelayanan } \\
\text { cepat tanggap }\end{array}$
\end{tabular}

\section{Desa}

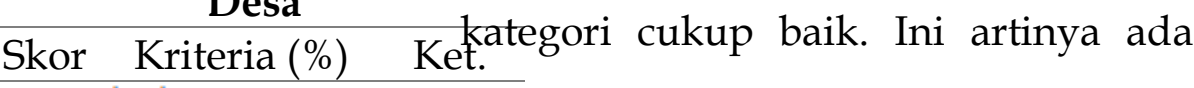
$525 \frac{525}{720} \times 100=73$ Cukperbezaan antara pelayanan publik di

$$
573 \frac{573}{720} \times 100=80 \text { Baik }
$$

Tabel 7 Hasil analisis skor dimensi

\begin{tabular}{|c|c|c|c|c|c|}
\hline \multirow{3}{*}{$\begin{array}{l}\text { Kesadaran } \\
\text { untuk } \\
\text { membantu } \\
\text { dan tidak } \\
\text { menyulitkan } \\
\text { konsumen }\end{array}$} & \multirow{3}{*}{$\begin{array}{l}551 \\
591\end{array}$} & $\frac{551}{720} \times 100=77$ & \multicolumn{3}{|c|}{$\begin{array}{l}\text { Baikassurance pelayanan publik aparatur } \\
\quad \text { desa }\end{array}$} \\
\hline & & $\frac{791}{720} \times 100=82$ & Baik Indikator & Desa & \\
\hline & & & & Skor Kriteria (\%) & Ket. \\
\hline Rata - rata & 560 & & $\begin{array}{l}\text { Baik Memiliki } \\
\text { pengetahuan, } \\
\text { dalam }\end{array}$ & $\begin{array}{l}\text { Cuk }^{44 \mathrm{kup}} \frac{544}{720} x 100=76 \\
\text { Baik }\end{array}$ & Baik \\
\hline & & & $\begin{array}{l}\text { memberi } \\
\text { pelayanan }\end{array}$ & $\frac{605}{720} \times 100=84$ & Baik \\
\hline
\end{tabular}

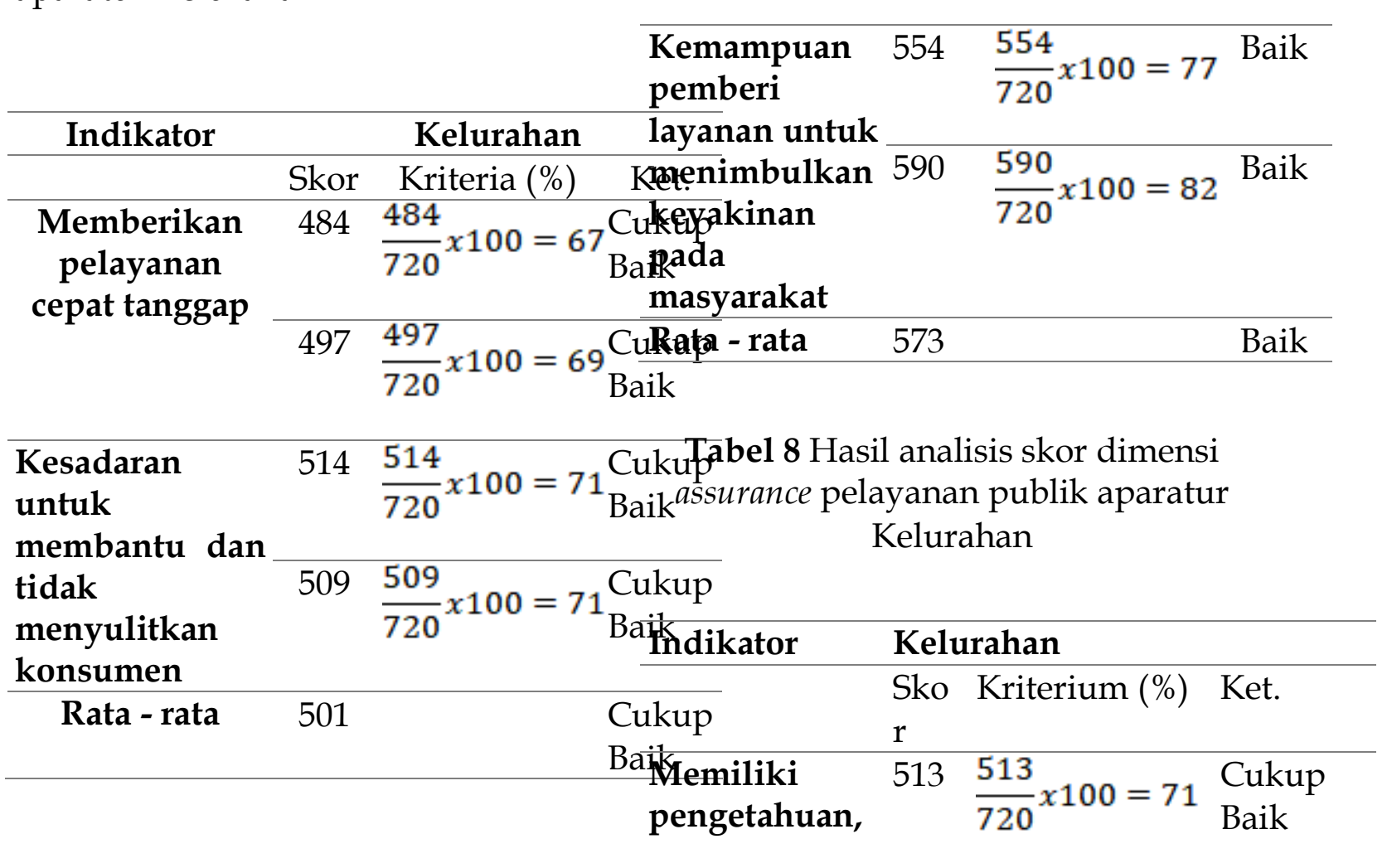




\begin{tabular}{|c|c|c|c|c|c|}
\hline $\begin{array}{l}\text { dalam } \\
\text { memberi }\end{array}$ & 518 & $\frac{518}{720} \times 100=72$ & Cukußata - rata & 566 & Baik \\
\hline
\end{tabular}

pelayanan

Tabel 10 Hasil analisis skor dimensi empahty pelayaanan publik aparatur

\begin{tabular}{|c|c|c|c|c|c|c|}
\hline $\begin{array}{l}\text { Kemampuan } \\
\text { pemberi } \\
\text { lavanan untuk }\end{array}$ & 508 & $\frac{508}{720} \times 100=71$ & $\begin{array}{l}\text { Cukupelurahan } \\
\text { Baik Indikator }\end{array}$ & & Kelurahan & \\
\hline menimbulkan & 520 & 520 & Cukup & Skor & Kriterium (\%) & Ket. \\
\hline $\begin{array}{l}\text { keyakinan } \\
\text { pada } \\
\text { masyarakat }\end{array}$ & & $\overline{720} \times 100=72$ & $\begin{array}{c}\text { Baik Kepedulian } \\
\text { dan } \\
\text { perhatian }\end{array}$ & 490 & $\frac{490}{720} \times 100=68$ & $\begin{array}{l}\text { Cukup } \\
\text { Baik }\end{array}$ \\
\hline Rata - rata & 515 & & $\begin{array}{l}\text { Cukupterhadap } \\
\text { Baik pengguna } \\
\text { layanan }\end{array}$ & 486 & $\frac{486}{720} \times 100=68$ & $\begin{array}{l}\text { Cukup } \\
\text { Baik }\end{array}$ \\
\hline \multicolumn{6}{|c|}{ Sedangkan dimensi terakhir dari } & $\begin{array}{l}\text { Cukup } \\
\text { Baik }\end{array}$ \\
\hline
\end{tabular}

adalah empathy Berdasarkan tabel 5 di bawah ini dapat dijelaskan bahwa

Tabel 11 Persentase Pelayanan Publik

pelayanan publik aparatur desa pada dimensi empahty dengan indikator kepedulian dan perhatian terhadap Desa pengguna layanan dengan skor ratarata 566. Sedangkan pada tingkat kelurahan hanya pada kategori cukup baik.

\begin{tabular}{cccc}
\hline $\begin{array}{c}\text { Kategor } \\
\text { i }\end{array}$ & \multicolumn{3}{c}{ Desa } \\
& Klasifikasi Sebaran/ & Frek. & Persen \\
& Interval & & \\
\hline Rendah & $X \leq(\mathrm{M}-1 \mathrm{SD})$ & 30 & $16,67 \%$ \\
& & & \\
\hline Sedang & $(\mathrm{M}+1 \mathrm{SD}) \leq \mathrm{X} \geq(\mathrm{M}-$ & 119 & $66,11 \%$ \\
& $1 \mathrm{SD}) 62,47 \leq \mathrm{X} \geq 42,52$ & & \\
\hline Tinggi & $\mathrm{X} \geq(\mathrm{M}+1 \mathrm{SD})$ & 31 & $17,22 \%$
\end{tabular}

Tabel 9 Hasil nalisis skor dimensi empahty pelayaanan publik aparatur desa

$$
X \geq 62,47
$$

$180 \quad 100 \%$

Tabel 12 Persentase Pelayanan Publik

\begin{tabular}{|c|c|c|c|c|c|c|}
\hline Indikator & & Desa & Kelurahar & & & \\
\hline & Skor & Kriteria (\%) & Ket. & & & \\
\hline Kepedulian & 551 & 551 & Baik Kategori & Kel & han & \\
\hline $\begin{array}{c}\text { dan } \\
\text { perhatian }\end{array}$ & 531 & $\frac{11}{720} \times 100=77$ & & $\begin{array}{c}\text { Klasifikasi } \\
\text { Sebaran/Interval }\end{array}$ & Frek. & Peratus \\
\hline $\begin{array}{c}\text { terhadap } \\
\text { pengguna } \\
\text { layanan }\end{array}$ & 580 & $\frac{580}{720} \times 100=81$ & BaikRendah & $\mathrm{X} \leq(\mathrm{M}-1 \mathrm{SD})$ & 30 & $16,61 \%$ \\
\hline
\end{tabular}




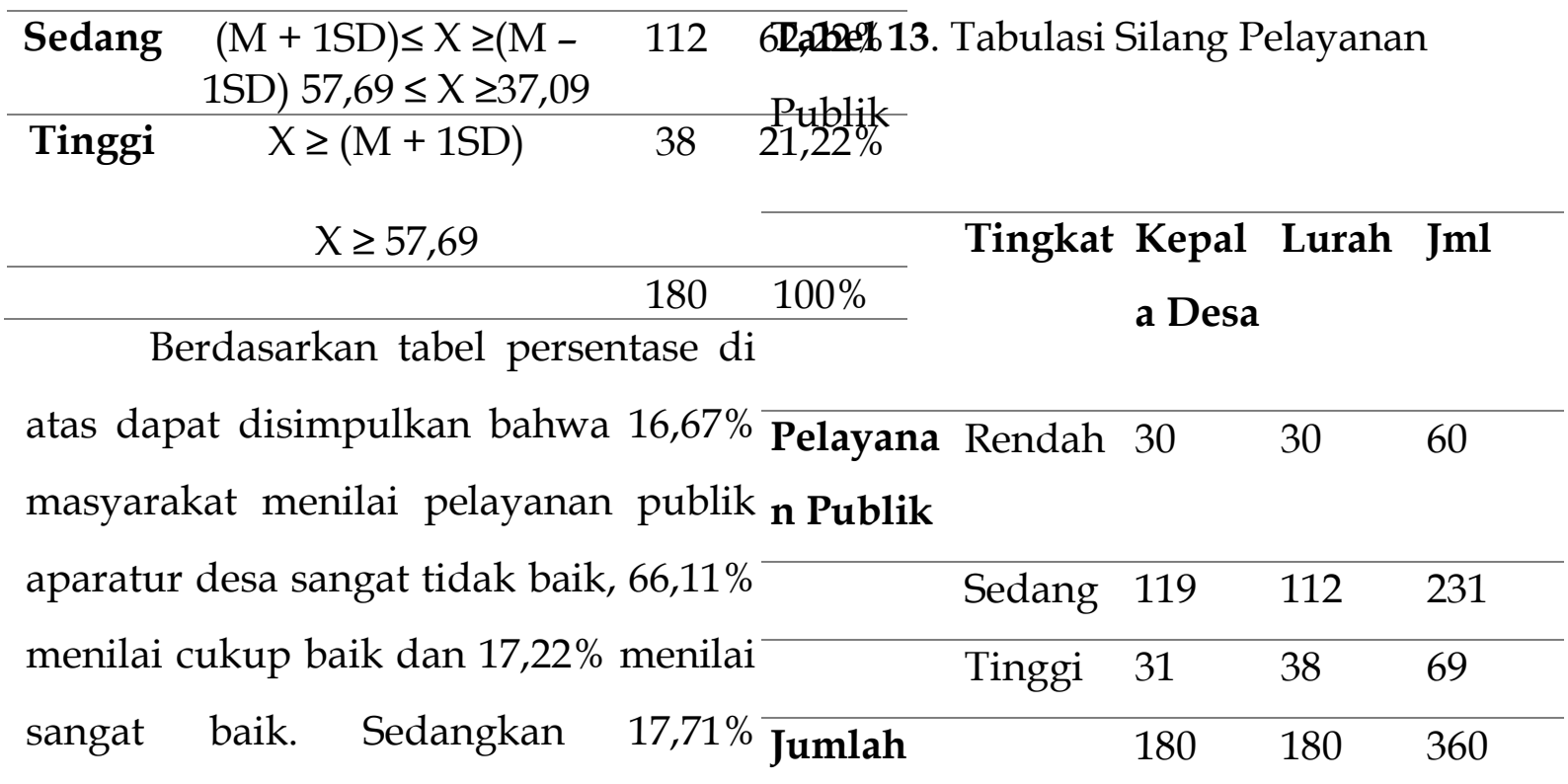

masyarakat menilai pelayanan publik aparatur kelurahan sangat tidak baik, Sedangkan untuk mengetahui 63,54\% menilai cukup baik dan $18,75 \%$ pengaruh sistem pemilihan kepala menilai sangat baik. desa dan pengangkatan lurah terhadap kinerja aparatur desa dan

Pengaruh Sistem Pemilihan Kepala Lurah dan Desa terhadap Pelayanan Publik

Frekuensi observasi pelayanan publik aparatur desa dan kelurahan berdasarkan sistem pemilihan kepala desa dan pengangkatan lurah pada dasarnya tidak jauh berbeda. Hal ini dapat dilihat pada table 7 di bawah ini. lurah, dapat dilihat pada table 8 , di mana pada tabel ini menunjukkan bahwa baris Kendall's tau-b menunjukkan harga $t_{b}=0,32$ dengan p-value $=0,531>0,05$ atau terima $\mathrm{H}_{0}$. Begitu pula pada baris Gamma menunjukkan harga $G=-0,62$ dengan v-palue $=0,531>0,05$ atau terima $\mathrm{H}_{0}$. Dari kedua hasil pengujian tersebut diperoleh kesimpulan bahwa tidak terdapat pengaruh pemilihan kepala desa dan pengangkatan lurah terhadap tinggi rendahnya pelayanan publik aparatur desa dan aparatur kelurahan. 
a. Not assuming the null hypothesis.

b. Using the asymptotic standard error Tabel 16 Test Statistics assuming the null hypothesis.

\section{Perbedaan Pelayanan berdasarkan}

\section{Sistem Pemilihan Kepala Desa dan}

Pengangkatan Lurah

Untuk mengetahui perbedaan pelayanan publik antara aparatur desa dengan kelurahan, maka dilakukan uji Mann- Whitney. Dari hasil uji ini ditemukan bahwa skor pelayanan publik aparatur desa yang menggunakan sistem pemilihan kepala desa dengan jumlah sampel sebanyak 180 dan nilai rata-rata rank nya adalah 206,46. Sedangkan skor pelayanan diperoleh harga $U=1,153$, dan $p$-value publik aparatur kelurahan yang $=0,00<0,05$ atau tolak $\mathrm{H}_{0}$. Sehingga menggunakan sistem pengangkatan dapat disimpulkan bahwa tidak
Skor

$\begin{array}{cr}\text { Mann-Whitney U } & 1.153 \\ \text { Wilcoxon W } & 2.782 \\ \text { Z } & -4.735 \\ \text { Asymp. Sig. (2- } & .000 \\ \text { tailed) } & \end{array}$

a. Grouping Variable:

Sistem
Berdasarkan tabel Test Statistics di atas pada baris Mann-Whitney $U$

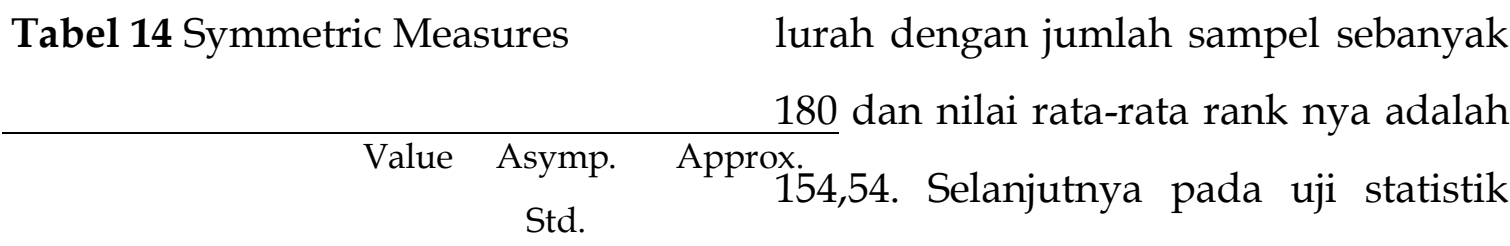

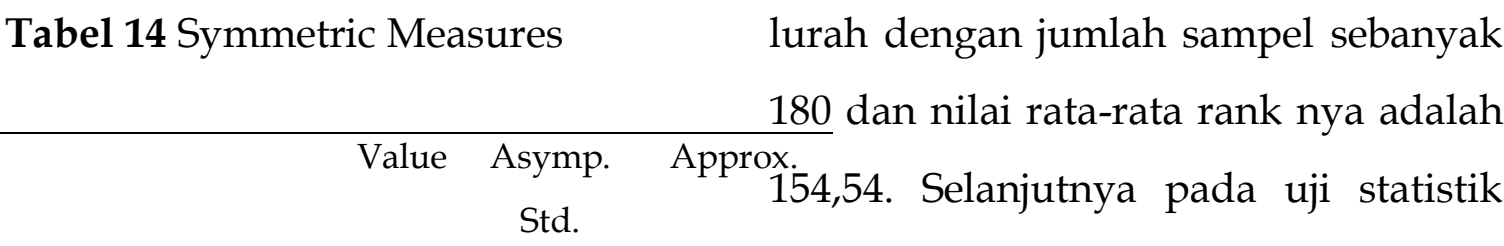

\begin{tabular}{crr} 
Tabel 14 Symmetric Measures & lurah dengan jumlah sampel sebanyak \\
& & 180 dan nilai rata-rata rank nya adalah \\
\hline Value & Asymp. & Approx. \\
& Std. & $154,54$. Selanjutnya pada uji statistik
\end{tabular}

\begin{tabular}{crr} 
Tabel 14 Symmetric Measures & lurah dengan jumlah sampel sebanyak \\
& & 180 dan nilai rata-rata rank nya adalah \\
\hline Value & Asymp. & Approx. \\
& Std. & $154,54$. Selanjutnya pada uji statistik
\end{tabular} Errora dapat dilihat pada tabel berikut:

$\mathrm{T}^{\mathrm{b}} \quad$ Sig.

Tabel 15 Ranks

$\begin{array}{llllll}\text { Ordinal tau-b } & .032 & .051 & .626 & .531\end{array}$

by tau-c .032

\begin{tabular}{|c|c|c|c|c|c|}
\hline 626. & .531 & Sistem & $\mathrm{N}$ & $\begin{array}{c}\text { Mean } \\
\text { Rank }\end{array}$ & $\begin{array}{c}\text { Sum of } \\
\text { Ranks }\end{array}$ \\
\hline 626. 099. & . 3 kor & $\begin{array}{c}\text { Kepala } \\
\text { Desa }\end{array}$ & 180 & 206.48 & 37162.50 \\
\hline & Total & Lurah & $\begin{array}{l}180 \\
360\end{array}$ & 154.54 & 27817.50 \\
\hline
\end{tabular}

$\mathrm{N}$ of Valid Cases $\quad 360$

Ordinal Gamm $\quad .062$

a Total 
terdapat perbedaan pelayanan publik di Kota Jambi dan Kabupaten Muaro antara aparatur desa dengan aparatur Jambi tidak dipengaruhi oleh variable kelurahan yang ada di Kota Jambi dan sistem pemilihan kepala desa dan Kabupaten Muaro Jambi. pengangkatan lurah. Pelayanan publik secara teoritis adalah memberikan PEMBAHASAN HASIL PENELITIAN

\section{PENGARUH SISTEM PEMILIHAN KEPALA DESA DAN PENGANGKATAN LURAH TERHADAP PELAYANAN PUBLIK}

Temuan penelitian menunjukkan bahwa sistem pemilihan kepala desa dan pengangkatan lurah tidak memiliki korelasi atau pengaruh terhadap pelayanan publik aparatur desa dan kelurahan dengan hasil Kendall's tau- $b$ menunjukkan harga $t_{b}=$ 0,32 dengan $p$-value $=0,531>0,05$ atau terima $\mathrm{H}_{0}$. Dari hasil pengujian tersebut berarti bahwa tidak terdapat pengaruh pemilihan kepala desa dan pengangkatan lurah terhadap pelayanan publik aparatur desa dan aparatur kelurahan di Kota Jambi dan Kabupaten Muaro Jambi.

Hal tersebut memberikan bukti empiris bahwa di dalam penelitian ini tinggi atau rendahnya variable pelayanan publik baik pelayanan publik aparatur desa maupun pelayanan publik aparatur kelurahan

pelayanan untuk memenuhi keperluan atau kepentingan masyarakat meliputi kualiti bukti fisik, kehandalan, daya tanggap, jaminan dan daya tanggap pelayan publik dalam memberikan pelayanan yang prima sesuai aturan yang telah ditentukan.

\section{PERBEDAAN PELAYAAN PUBLIK} ANTARA APARATUR DESA DENGAN KELURAHAN BERDASARKAN SISTEM PEMILIHAN KEPALA DESA DAN PENGANGKATAN LURAH

\section{Temuan}

penelitian menunjukkan bahwa tidak ada perbedaan pelayanan publik antara aparatur desa dengan pelayanan publik aparatur kelurahan dengan hasil uji Mann-Whitney $U$ diperoleh harga $\mathrm{U}=1,153$, dan $\mathrm{p}$-value $=0,00<0,05$ atau tolak $\mathrm{H}_{0}$. Dari hasil pengujian tersebut berarti bahwa terdapat perbedaan pelayanan publik antara aparatur desa dengan aparatur kelurahan berdasarkan sistem pemilihan kepala 
desa dan pengangkatan lurah di Kota seharusnya diberikan dengan lebih Jambi dan Kabupaten Muaro Jambi. baik. Meskipun ada perbedaan antara

Hal tersebut memberikan bukti empiris bahwa di dalam penelitian ini pelayanan publik aparatur desa yang dipimpin oleh Kepala Desa dengan pelayanan publik di desa dengan di tingkat kelurahan, tetapi perbedaan tersebut tidak begitu besar.

sistem pemilihan berbeda dengan bahwa dengan pengangkatan lurah dengan pelayanan publik aparatur oleh pejabat di atasnya, maka kelurahan yang dipimpin oleh Lurah persoalan konflik, korupsi dan dana dengan sistem pengangkatan. Selain yang harus dikeluarkan oleh berdasarkan hasil uji Mann-Whitney $U$, pemerintah untuk mengangkat lurah bukti empiris adanya perbedaan tidak sebesar pemilihan kepala desa, pelayanan publik antara aparatur desa jika hasil yang diperoleh di dalam dengan aparatur kelurahan dapat juga memberikan pelayan publik relatif dilihat pada nilai rata-rata (mean) hampir sama, ini kerana tujuan pelayanan publik aparatur desa sebesar diangkatnya pejabat ataupun 52,49 dan nilai rata-rata (mean) pemimpin adalah untuk memberikan pelayanan publik aparatur kelurahan pelayanan terbaik kepada masyarakat. sebesar 47,39 .

\section{SIMPULAN}

Dari hasil pengukuran di atas menunjukkan bahwa sistem demokrasi pada tingkat bawah khsusnya di dalam pemilihan kepala desa tidak memberi pengaruh terhadap pelayanan publik di desa dan begitu juga dengan pengangkatan lurah dari kelima aspek yang diteliti. Ada faktor lain yang mempengaruhi pelayanan publik yang
Oleh itu dianjurkan bahwa perlu ada mekanisme aturan di dalam pengawasan terhadap pelayanan publik baik di desa dan juga di tingkat kelurahan sehingga dengan adanya mekanisme pengawasan ini maka pelayanan publik dapat ditingkatkan lagi. 


\section{PENGHARGAAN}

Ucapan terima kasih ditujukan kepada Universitas Islam Negeri Jambi (UIN) Sulthan Thaha Saifuddin Jambi melalui Lembaga Penelitian dan Pengembangan Masyarakat (LP2M) yang telah memberikan bantuan dana penelitian ini. Penelitian ini pertama sekali dilaksanakan untuk mengukur kinerja aparatur desa dan lurah. Tetapi dengan persoalan demokrasi yang berkembang di desa dan tuntutan lurah yang menginginkan kedudukan yang sama dengan desa, maka dengan bantuan saudara Indra Fauzan, penelitian ini dikembangkan menjadi pelayanan publik karena ini bersentuhan langsung dengan masyarakat. Sebagai bentuk penghargaan kepala beliau, tulisan ini menjadi tulisan bersama.

\section{DAFTAR PUSTAKA}

Aspinall, E. \& Rohman, N. (2017). "Village Head Elections in Java: Money Politics and Brokerage in the Remaking of Indonesia's Rural Elite." Journal of Southeast Asian Studies 48 (01): 31-52. https://doi.org/10.1017/S0022463 416000461.
Dwiyanto, A. (2006). Mewujudkan Good Governance Melalui Pelayanan Publik. Yogyakarta: GM Publisher.

Dwiyanto. A. (2015). Manajemen Pelayanan Publik: Peduli. inklusif dan kolaboratif. Yogyakarta: Universitas Gadjah Mada Press

Fadhilah, P. (2012). New Public Governance. Malang. UB Press.

Fitriyah. (2015). "Cara Kerja Politik Wang (Studi Kasus Pilkada Dan Pilkades Di Kabupaten Pati)." Politika 6 (2): 101-11.

Harsanto, B, T Slamet, R, W. \& Simin. (2017). "Penguatan Kelembagaan Kelurahan Pasca Implementasi UU No. 23 Tahun 2014 tentang Pemerintahan Daerah." Masyarakat, Kebudayaan dan $\begin{array}{llll}\text { Politik } 30 & 30 & \text { (2): } 188 .\end{array}$ https://doi.org/10.20473/mkp.V30 I22017.188-196.

Indonesian Corruption Watch. (2018). "Outlook Dana Desa 2018 Potensi Penyalahgunaan Anggaran Desa Di Tahun Politik." https://antikorupsi.org/sites/default /files/outlook_desa_2018__icw.pdf.

Kartika, R, S. (2016). "Concurrent Village Head Election (Pilkades) Disputes (Analysis of Handling Pattern and Dispute Resolution Process in Tapos, Talagasari, and Dukuh Villages of Tangerang Regency)." Jurnal Bina Praja 8 (2): 253-62. https://doi.org/10.21787/jbp.08.20 16.253-262.

Keputusan Menteri Pendayagunaan Aparatur Negara Nomor 63/KEP/M.PAN/\&/2003 tentang 
Pedoman Umum Penyelenggaraan Pelayanan Publik.

Kingsley, J, J. (2012). "Village Elections, Violence and Islamic Leadership in Lonfibok, Eastern Indonesia^." Journal of Social Issues in Southeast Asia 27 (2): 26.

Pasolong, H. (2007). Teori Administrasi Publik. Bandung: Alfabeta.

Savas. E. S. (1987). Privatization: The Key to Better Governance. New Jersey. Chattam House Publisher.

Sinambela. L.P. (2006). Reformasi Pelayanan Publik. Jakarta : Bumi Aksara.

Tempo. (2016). Pemilihan Kepala Desa Lebih Mahal daripada Pilkada, Mengapa?atas talian https://nasional.tempo.co/read/812 814/pemilihan-kepala-desa-lebihmahal-daripada-pilkadamengapa/full\&view=ok, $\quad 8$ Februari 2019.

Tempo. (2015). Jadi Korban Pungli Rp 65 Juta, Calon Kades Lapor Pold.

Atas talian. https://nasional.tempo.co/read/693 585/jadi-korban-pungli-rp-65-jutacalon-kades-lapor-

polda/full\&view=ok. 8 Februari 2019.

Tribunejateng.com 2018. Dana setiap desa berbeda, ini rincian anggaran Pilkades serentak Kabupaten Tega. Atas talian http://jateng.tribunnews.com/2018/08/03/ dana-setiap-desa-berbeda-ini-rinciananggaran-pilkades-serentak-kabupatentegal. 8 Februari 2019.

Tribunnews. 2015. Fantasts! Biaya pendaftaran calon kades di OKI dipatok 39 juta. Atas talian: http://www.tribunnews.com/regio nal/2015/05/29/fantasts-biayapendaftaran-calon-kades-di-okidipatok-rp-39-juta. 8 Februari 2019.

Yuningsih, Neneng Yani, and Valina Singka Subekti. 2016. "Demokrasi dalam Pemilihan Kepala Desa? Studi Kasus Desa Dengan Tipologi Tradisional, Transisional, dan Modern di Provinsi Jawa Barat Tahun 2008-2013." Jurnal Politik 1 https://doi.org/10.7454/jp.v1i2.21. 